\title{
SELECTING COMMON BEAN BREEDING POPULATIONS VIA MIXED MODELS
}

\author{
SELEÇÃO DE POPULAÇÕES SEGREGANTES DE FEIJÃO COMUM POR MEIO DE \\ MODELOS MISTOS
}

\author{
Ramon Gonçalves de PAULA ${ }^{1}$; Igor Gonçalves de PAULA ${ }^{1}$; Ana Laura Nicomedes CARNEIRO²; \\ Felipe Vicentino SALVADOR ${ }^{1}$; José Eustáquio de Souza CARNEIRO \\ Pedro Crescêncio Souza CARNEIRO ${ }^{1}$ \\ 1. Department of Biology, Federal University of Viçosa, Viçosa, MG, Brazil. ramondepaula22@ gmail.com; 2. Department of \\ Agriculture, Federal University of Viçosa, Viçosa, MG, Brazil
}

\begin{abstract}
Choosing breeding populations in a common bean (Phaseolus vulgaris L.) breeding program via recurrent selection is a crucial step since it maximizes the effort to find superior inbred lines. The application of the mixed models methodology (REML/BLUP) in predicting breeding values has shown good results in animal and perennial crops breeding programs. Conversely, studies on the application of this methodology to annual crops are still scarce. The present work aimed to use the REML/BLUP methodology to select breeding populations of a common bean breeding program via recurrent selection. Thirty-five $\mathrm{F}_{3}$ populations were evaluated. Individual plants data were assessed for grain yield and hypocotyl diameter, and the genetic potential of the population was estimated via the mixed models and the Jinks and Pooni's methodologies. A selection index was applied to the selection among and within population, considering both characters simultaneously, using the population and individual BLUP means. REML/BLUP has shown to be a feasible methodology to predict and select the potential of breeding populations, considering more than one character. Selecting individual plants within population provides positive genetic gain estimates for both characters. BLUP breeding values are fundamental to the choice of the number of populations and single plants to be conducted in a common bean breeding program via recurrent selection.
\end{abstract}

KEYWORDS: Phaseolus vulgaris. Selection index. Recurrent selection. Self-pollinated crop.

\section{INTRODUCTION}

Most traits in common bean (Phaseolus vulgaris L.) are controlled by several loci, and favorable alleles are present in different lines. Hybridization is widely used in common bean breeding program to gather favorable alleles in a single inbred line. This method can generate several populations, which are usually improved by the recurrent selection strategy. However, the use of several populations can hinder the breeder's work in conducting these populations to homozygosity. In addition, the assessment of quantitative traits requires the evaluation of progenies, which are derived by selecting individual plants within population. Choosing the best breeding populations and plants is a crucial step in a breeding program via recurrent selection since it maximizes the use of human and financial resources (Alves et al. 2015; Bernardo, 2012; Mendes et al., 2012; Pires et al. 2014; Silva et al. 2010).

The Jinks and Pooni's (1976) methodology has assisted bean breeders in choosing the best breeding populations (Cunha et al., 2005; Menezes Júnior et al., 2016; Otubo et al., 1996; Rocha et al.,
2013). However, this methodology is based only on individual plants data, which varies among populations due to differences in the final stand. This fact is one of the main impairments affecting the implementation of balanced experiments. Furthermore, the population evaluation excludes the existence of experiments with replications. Thus, the Jinks and Pooni's methodology hinders a highly accurate estimation of variance components (Menezes Júnior et al., 2016).

The mixed models methodology consists of estimating variance components via restricted maximum likelihood (REML) and using the best linear unbiased predictor (BLUP) to predict the genetic values (Henderson, 1984; Mendes et al., 2012; Piepho et al., 2008; Bernal-Vasquez et al., 2016). Moreover, this methodology provides the BLUP of each plant, even under unbalanced conditions. Thus, the mixed models methodology allows the selection among and within populations, increasing the success of the population breeding process. Only a few studies have reported the use of this methodology in common bean. Therefore, this work aimed to use the REML/BLUP methodology in selection among and within breeding populations 
in common bean breeding program via recurrent selection.

\section{MATERIAL AND METHODS}

Thirty-five populations were generated from a partial diallel scheme, consisting of five black bean parents (Group I) and seven carioca bean parents (Group II) (Table 1). These populations, together with the 12 parents (checks), were evaluated in the $F_{3}$ generation, in an experiment carried out in the municipality of Coimbra, state of Minas Gerais, Brazil (lat. $20^{\circ} 45^{\prime}$ S; long. and $42^{\circ} 51^{\prime}$ $\mathrm{W}$; alt. $690 \mathrm{~m}$ asl), during the 2014 winter season.
PAULA, R. G. et al.

The experiment consisted of a randomized blocks design, with three replications. Plots consisted of four 4-meters $(\mathrm{m})$ rows, spaced at $0.50 \mathrm{~m}$. One of the central rows was harvested for subsequent individual evaluation of grain yield (GY), in grams per plant ( $\left.\mathrm{g} \mathrm{plant}^{-1}\right)$; and hypocotyl diameter (HD), in millimeters $(\mathrm{mm})$, measured at 1 centimeter $(\mathrm{cm})$ below the cotyledon node.

Data were subject to Deviance analysis. The maximum likelihood ratio (LRT) was used to check the significance of population effect at mean level, considering $1 \%$ of probability. The mean of each population was estimated considering all the plants evaluated in the three replications.

Table 1. Information on origin, seed type, architecture, and disease resistance of the 12 parents used in partial diallel crosses

\begin{tabular}{ccccc}
\hline Parents & Origin & Seed type (Diallel group) & Architecture & Resistance \\
\hline L20 & UFV & Black (Group I) & Semierect & Rust/Anthracnose \\
Xamego & PESAGRO/EMBRAPA & Black (Group I) & Erect & Fusarium wilt \\
BRS Expedito & EMBRAPA & Black (Group I) & Erect & - \\
BRS Valente & EMBRAPA & Black (Group I) & Erect & Anthracnose \\
Diamante Negro & EMBRAPA/EMGOPA & Black (Group I) & Semierect & Bacteriosis \\
VC 12 & UFV & Carioca (Group II) & - & Rust \\
VC 20 & UFV & Carioca (Group II) & Semierect & Rust \\
BRS Estilo & EMBRAPA & Carioca (Group II) & Erect & Rust \\
CNFC 10720 & EMBRAPA & Carioca (Group II) & Erect & White mold \\
MAI 1813 & UFLA & Carioca (Group II) & - & Angular leaf spot \\
VC 16 & UFV & Carioca (Group II) & Semierect & Angular leaf spot \\
BRSMG Uai & UFLA & Carioca (Group II) & Erect & Fusarium wilt \\
\hline Sours: Adapted from
\end{tabular}

Sourse: Adapted from MOURA, $2013 \quad$-: No information.

\section{Predicting the genetic potential of the breeding populations}

The genetic potential of the breeding populations was estimated via the BLUP of their genetic values. The greater the genetic value of the population, the greater was the potential to extract superior inbred lines from it.

The genetic-statistic model used to estimate the variance components and the BLUPs of both population and individual genetic values are given in a two-step process. The first step, which intends to obtain the BLUP values of individual plants, is described as follow:

$y=\boldsymbol{X} r+\boldsymbol{Z} a+\boldsymbol{W} p+\boldsymbol{T} b+e$

where $y$ is the data vector; $r$ is the checks and the set of the populations effect vector (assumed as fixed); $\boldsymbol{a}$ is the vector of individual additive genetic effect (assumed as random); $p$ is vector of plot effect (assumed as random); $b$ is the vector of block effect (assumed as random); $e$ is the vector of error (random). $\mathbf{X}, \mathbf{Z}, \mathbf{W}$, and $\mathbf{T}$ are the incidence matrices for $r, a, p$, and $b$ effects, respectively.

The second step consisted of obtaining the BLUP of the population genetic value, which is given by the following model:

$y=\boldsymbol{X} r+\boldsymbol{Z} g+\boldsymbol{W} p+\boldsymbol{T} b+e$

where $g$ is the population genetic effect, and the other effects are identical to model 1 , as well as the mean and variance structure and the mixed model equations.

The estimation of additive variance $\left(\sigma_{\mathrm{a}}^{2}\right)$ using $F_{3}$ generation data implies assuming 0.25 of the dominance variance $\left(\sigma_{d}^{2}\right)$, which tends to zero both among and within-population variation. However, even without this assumption, the little portion of $\sigma_{\mathrm{d}}^{2}$ will not affect the rank since both heritabilities (among and within populations) are used to calculate the BLUP of the genetic values. 
The proportionality between heritabilities will not be affected since both are inflated by the same amount of $\sigma_{\mathrm{d}}^{2}$ (Resende, 2007).

The SELEGEN-REML/BLUP software was used to predict the individual and population genetic values (Resende, 2016).

For comparison purpose, the potential of the breeding populations was also predicted via the Jinks and Pooni's methodology (1976). For this methodology, each population was represented by the set of plants from the three replications, regardless of the experimental design.

\section{Selection among and within a breeding population}

Common bean breeding programs conducted via recurrent selection usually work with a total of 20 populations, and at the evaluation step, 19 progenies are obtained from each population. Those 380 progenies are evaluated in a $20 \times 20$ lattice scheme, together with 20 checks (Alves et al., 2015; Batista et al., 2017; Resende et al., 2016). In this sense, 20 breeding population and 19 plants within each population were selected to start a common bean program via recurrent selection.

A selection index was used for the selection among and within population, aiming at obtaining balanced genetic gains for both characters simultaneously. Therefore, the BLUPs of the genetic values for HD and GY were standardized and summed up. This procedure is known as the additive selection index.

The selection within each population allows predicting a new mean $\left(\bar{X}_{i}\right)$ and a selection gain $\left[G S_{i}(\%)\right]$, as follow:

$$
\bar{X}_{i}=G_{a c}+\bar{X}
$$

where $G_{a c}$ is the accumulated genetic gain, given by the mean of genotypic effects of the 19 selected individuals; and $\bar{X}$ is the overall mean of the character. given by:

The selection gain to an $i$ population is

$$
G S_{i}(\%)=\left(100 * \frac{\bar{X}_{i}}{\bar{X}}\right)-100
$$

\section{Selecting individual plants}

At the end of each cycle in a recurrent selection program for a self-pollinated crop, the breeder has the option to extract improved inbred lines from the populations (Bernardo, 2012). Thus, the best plants were selected, regardless of their population, for HD and GY. Similarly to the selection among and within population, the additive selection index was also used in this step. The new mean and the selection gain from the populations to which those plants belong were also estimated.

\section{RESULTS}

\section{Deviance analysis and genetic parameters}

Based on the Deviance analysis, the genetic effect of the population was significant for both characters, indicating genetic variability among the breeding populations. Most of the total phenotypic variance is related to the phenotypic variance within plot, which corresponded to $91.5 \%$ for HD and 91.9\% for GY (Table 2).

Heritability estimates at the population mean level was $77 \%$ for HD and $71 \%$ for PY, while heritability estimates of individual plants were much lower, $6 \%$ for $\mathrm{HD}$ and $5 \%$ for GY. The estimates of accuracy were $88 \%$ for $\mathrm{HD}$ and $84 \%$ for GY in the selection among population, and $24 \%$ for HD and $22 \%$ for GY, in the selection within population (Table 2). The accuracy values for the selection among population are classified as high. Conversely, the accuracy values for the selection of individual plants are classified as low (Resende and Duarte, 2007).

\section{Predicting the genetic potential of the breeding population}

The mixed models and the Jinks and Pooni's methodologies were equivalent in indicating the potential of the breeding population, mainly of those with the highest potential (best ranked). This result is shown in Figure 1 as a linear regression between both methodologies in the rank of the 35 populations. The coefficient of determination for HD and GY was $89 \%$ and $96 \%$, respectively, revealing a high regression adjustment between the two methodologies. The estimates of the Spearman's correlation between the two methodologies for the rank of the breeding populations were also high for both characters $(0.94$ and 0.98 , for HD and GY, respectively). The equivalence between the methodologies was higher when quantifying the genetic potential of GY than when quantifying the genetic potential of HD. 
Table 2. Parameters estimates regarding hypocotyl diameter (HD) and grain yield (GY), evaluated in 35 common bean $\mathrm{F}_{3}$ populations

\begin{tabular}{lcc}
\hline \multicolumn{1}{c}{ Parameter $^{*}$} & HD & GY \\
\hline Additive variance among populations & 0.083 & 5.379 \\
Individual additive variance within population & 0.042 & 2.690 \\
Phenotypic variance within plot & 1.269 & 101.545 \\
Total phenotypic variance & 1.385 & 110.489 \\
Narrow-sense population heritability (\%) & 77 & 71 \\
Population selection accuracy (\%) & 88 & 84 \\
Narrow-sense individual heritability (\%) & 6 & 5 \\
Individual selection accuracy $(\%)$ & 24 & 22 \\
\hline
\end{tabular}

*: Heritabilities and accuracies estimates were based on the BLUP values.

A

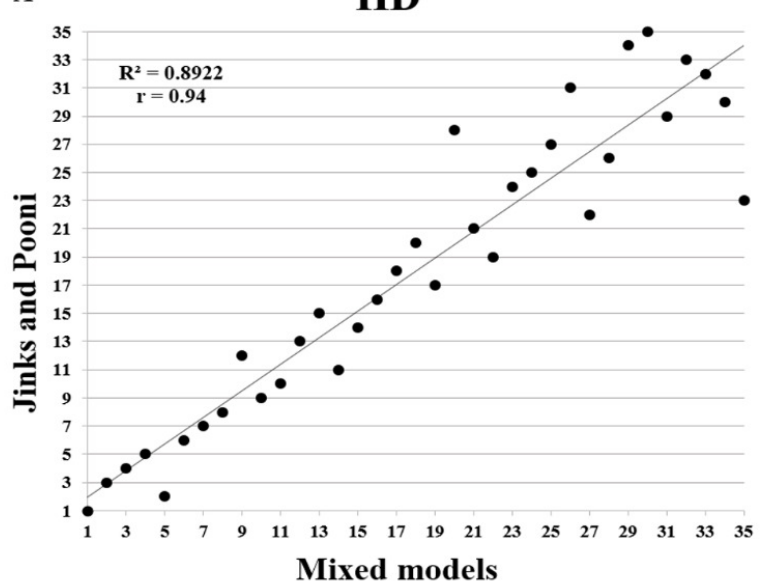

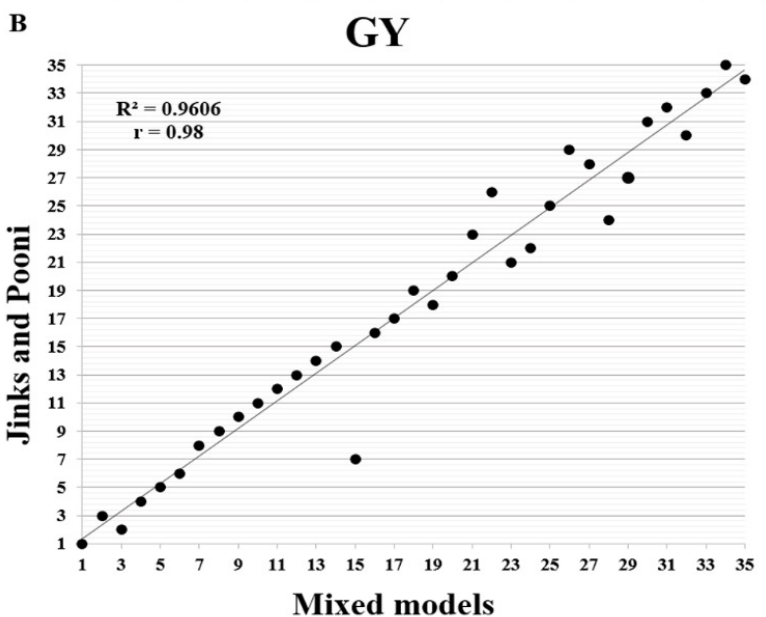

B Mixed models

Figure 1. Linear regression between the Jinks and Pooni's methodology (ordinate) and BLUP (abscissa) in the rank of the 35 breeding populations, regarding hypocotyl diameter (HD) (A) and grain yield (GY) (B)

\section{Selection among and within population}

The top 20 breeding populations were selected based on the additive selection index, by assigning equal weights to the two characters. Selection gain estimates of the populations were $3.1 \%$ and $7.6 \%$ for $\mathrm{HD}$ and GY, respectively.

A new population mean and the genetic gain could be estimated after selecting 19 plants within each one of the 20 top populations. The estimated gain of the 380 selected individuals was $4.3 \%$ for HD and $10.8 \%$ for GY. Results also show that the top 15 populations had positive gains for both characters, while the other five worse-ranked populations showed a negative gain for at least one of the characters (Table 3).

\section{Selection of individual plants}

The selection gain of the 380 best individual plants, regardless of the population, was $6.5 \%$ and $22.2 \%$ for HD and GY, respectively. This selection led to higher gains when compared with the 380 individuals selected among and within populations. Out of the 35 breeding populations, only ten contributed to the selection of the 380 best individuals. Furthermore, the parent BRS Valente provided 235 of the 380 individuals selected among those ten populations, corresponding to $61.8 \%$ of the total of selected plants. Therefore, BRS Valente is a promising parent to generate superior bean lines with high HD and GY (Table 4). 
Table 3. Prediction of new mean and genetic gain in 19 plants selected within the 20 best populations for hypocotyl diameter (HD) and grain yield (GY)

\begin{tabular}{cccccc}
\hline & \multicolumn{2}{c}{ New mean } & & \multicolumn{2}{c}{ Genetic gain } \\
\cline { 2 - 3 } \cline { 5 - 6 } Population & HD & GY & & HD & GY \\
\hline BRS VALENTE X CNFC 10720 & 5.68 & 21.09 & & $6.6 \%$ & $35.6 \%$ \\
BRS VALENTE X RP1 & 5.76 & 18.99 & & $8.0 \%$ & $22.1 \%$ \\
TB9401 X VC12 & 5.74 & 18.83 & & $7.7 \%$ & $21.1 \%$ \\
TB9401 X CNFC 10720 & 5.60 & 19.63 & & $5.0 \%$ & $26.2 \%$ \\
BRS VALENTE X VC12 & 5.86 & 17.64 & & $9.8 \%$ & $13.4 \%$ \\
DIAMANTE NEGRO X RP1 & 5.65 & 18.87 & & $5.9 \%$ & $21.3 \%$ \\
DIAMANTE NEGRO X VC12 & 5.52 & 19.48 & & $3.5 \%$ & $25.2 \%$ \\
BRS VALENTE X VC16 & 5.76 & 17.26 & & $8.0 \%$ & $11.0 \%$ \\
BRS VALENTE X VC20 & 5.82 & 15.84 & & $9.2 \%$ & $1.8 \%$ \\
BRS VALENTE X MAI1813 & 5.56 & 17.43 & & $4.3 \%$ & $12.1 \%$ \\
TB9401 X VC16 & 5.64 & 16.42 & & $5.8 \%$ & $5.6 \%$ \\
XAMEGO X RP1 & 5.55 & 16.36 & & $4.1 \%$ & $5.2 \%$ \\
L20 X RP1 & 5.61 & 15.78 & & $5.1 \%$ & $1.5 \%$ \\
XAMEGO X CNFC 10720 & 5.47 & 16.58 & & $2.6 \%$ & $6.6 \%$ \\
TB9401 X RP1 & 5.45 & 15.66 & & $2.2 \%$ & $0.7 \%$ \\
XAMEGO X VC12 & 5.51 & 14.55 & & $3.4 \%$ & $-6.5 \%$ \\
L20 X CNFC 10720 & 5.22 & 16.78 & & $-2.1 \%$ & $7.9 \%$ \\
XAMEGO X VC16 & 5.49 & 14.58 & & $2.9 \%$ & $-6.2 \%$ \\
TB9401 X VC20 & 5.04 & 17.54 & $-5.5 \%$ & $12.8 \%$ \\
Overall mean & 5.27 & 15.44 & $-1.2 \%$ & $-0.7 \%$ \\
\hline DIAMANTE NEGRO X CNFC 10720 & 5.56 & 17.24 & & $4.3 \%$ & $10.8 \%$ \\
\hline
\end{tabular}

Table 4. Prediction of new mean and genetic gain in the selection of the 380 best plants, regardless of the population, for hypocotyl diameter (HD) and grain yield (GY)

\begin{tabular}{|c|c|c|c|c|c|}
\hline \multirow[b]{2}{*}{ Populations $^{1}$} & \multirow{2}{*}{$\begin{array}{l}\text { Number } \\
\text { of plants }\end{array}$} & \multicolumn{2}{|c|}{ New mean } & \multicolumn{2}{|c|}{ Genetic gain } \\
\hline & & $\mathrm{HD}$ & GY & HD & GY \\
\hline BRS VALENTE x CNFC 10720 & 92 & 5.63 & 20.57 & $5.6 \%$ & $32.3 \%$ \\
\hline BRS VALENTE x RP1 & 91 & 5.71 & 18.53 & $7.1 \%$ & $19.1 \%$ \\
\hline TB9401 x VC12 & 57 & 5.70 & 18.47 & $6.9 \%$ & $18.8 \%$ \\
\hline BRS VALENTE $x$ VC12 & 46 & 5.84 & 17.35 & $9.5 \%$ & $11.6 \%$ \\
\hline TB9401 x CNFC 10720 & 44 & 5.58 & 19.33 & $4.6 \%$ & $24.3 \%$ \\
\hline DIAMANTE NEGRO x RP1 & 33 & 5.64 & 18.73 & $5.8 \%$ & $20.4 \%$ \\
\hline DIAMANTE NEGRO x VC12 & 11 & 5.54 & 19.68 & $3.9 \%$ & $26.5 \%$ \\
\hline BRS VALENTE $x$ VC16 & 4 & 5.79 & 17.70 & $8.6 \%$ & $13.8 \%$ \\
\hline BRS VALENTE $x$ VC20 & 1 & 5.86 & 16.73 & $9.9 \%$ & $7.5 \%$ \\
\hline BRS VALENTE x MAI 1813 & 1 & 5.63 & 18.44 & $5.5 \%$ & $18.6 \%$ \\
\hline Total & 380 & 5.68 & 19.00 & $6.50 \%$ & $22.20 \%$ \\
\hline
\end{tabular}

1: The other populations did not contribute to any of the selected plants, based on the index. 


\section{DISCUSSION}

\section{Deviance analysis and genetic parameters estimation}

The significant effect of populations by the deviance analysis suggests that the variability among populations, for both characters, originates from the genetic difference between the parents. These results corroborate those of Moura et al. (2016), who found a significant difference between the two groups of parents for grain yield and plant architecture in a diallel analysis study. Common bean plants with a desirable architecture are positively correlated with higher HD values. Thus, populations with high genetic variability for HD, associated with high genetic variability for GY, have great chances to obtain erect and yielding lines, which are the goals of most common bean breeding programs (Moura et al., 2013; Pires et al., 2014).

Selection among populations is efficient, as evidenced by the high values of heritability and selective accuracy at mean population level. These estimated values are originated from a high number of plants per population, resulting in low estimates of residual variance and high reliability of the selective process (Holland et al., 2003; Nyquist and Baker, 1991).

Individual-based selection is less efficient for both characters, considering the values of the estimates of individual heritability and selective accuracy, which results in poor efficiency when using mass selection. These values are associated with high environmental influence on individual plant data. Oliveira et al. (2015) also reported low estimates of individual heritability for $\mathrm{HD}$, associating the great environment influence in the obtainment of individual phenotypic data. Other studies using individual plant data in common bean have already been reported in the literature, which highlighted the difficulty in obtaining reliable values for mass selection (Menezes Júnior et al., 2016 Rocha et al., 2013). Westneat et al. (2015) reported that errors associated with individual plant measurements are unavoidable for they are not homogeneous at the sampling time, and each plant can uniquely interact with the environment.

\section{Prediction of breeding populations potential}

The equivalence between the mixed model and the Jinks and Pooni's methodologies in indicating the most promising populations to be included in a recurrent selection program confirms that both can be used for this purpose. The Jinks and Pooni's methodology has been routinely used in annual crops, leading to satisfactory results (Cunha et al., 2005, Menezes Júnior et al., 2016, Morais Júnior et al., 2015, Rocha et al., 2013). However, reliable estimates of the genetic parameters of the populations cannot be obtained, nor can the individual genetic values. In this sense, the REML/BLUP methodology is more advantageous for being considered as an optimal process to estimate genetic parameters. It also enables the selection of plants based on their predicted genetic values, taking into account the relationship among plants (Cowling, 2013; Resende, 2007; Viana et al., 2010).

Another advantage of the REML/BLUP methodology over the Jinks and Pooni's methodology is the possibility of selecting the best populations considering more than one character by the additive selection index. This fact is beneficial for selection based on the genetic value, instead of the phenotypic value. According to Entringer et al. (2016), the additive selection index based on REML/BLUP is more efficient when compared with other selection indices, such as those based on the least squares. Thus, the selection index based on BLUP values is appropriate to select the best population considering more than one character.

\section{Selection among and within populations}

Selection of the best populations based on HD values resulted in positive gains for both characters, which indicates that HD and GY are positively correlated. Pires et al. (2014) reported positive gains for plant architecture and grain yield in one cycle of recurrent selection when the selection was based only on plant architecture. Jost et al. (2014) found similar results. Due to high accuracy values for both characters, equal selection for both characters implies positive gains when using BLUP mean values.

The Jinks and Pooni's methodology allows selecting more promising populations. The plants that will originate the progenies are randomly selected. On the other hand, the REML/BLUP methodology enables selection within population, besides estimating the selection gain by the selection of a given number of plants per population.

The present results indicate the need to reduce the number of populations to be conducted in a common bean recurrent selection program, instead of selecting a fixed number of 20 populations (Table 3 ). The number of parents that contributed to the selection among and within the 15 best populations is the same when considering the 20 best populations, which guarantees the maintenance of 
genetic variability. The disposal of the last five selected populations would not hinder the recurrent selection process since the estimated gains for at least one of the characters were negative. A desirable strategy to be applied to a self-pollinating crop breeding program would be to work with a small number of breeding populations (Witcombe, 2001). Selections based on BLUP values of population and individuals within population can help the breeder identify the most appropriate number of populations to be used in the recurrent selection breeding program.

\section{Selection of individual plants}

At the end of each recurrent selection cycle, new inbred lines are generated to be used in other assays. Selection based on the best individuals, regardless of the population, allows the breeder to obtain more expressive gains for both characters. The large number of individuals selected from BRS Valente indicates that this parent has a larger number of favorable alleles for HD and GY, suggesting that the lines from these plants may have a high potential in the black bean breeding program.

The advantage of mixed models at this stage of the breeding program is due to the fact that using individual BLUP is more reliable than selecting plants by their phenotypic value. The main reason for this advantage owes to the fact that BLUP relies on the population genetic merit to predict the individual genetic value (Bauer, 2006, Cowling, 2013). Thus, selecting individual plants via BLUP values should be indicated at this stage when seeking improved inbred lines.

\section{ACKNOWLEDGMENT}

The authors thank FAPEMIG (Fundação de Amparo à Pesquisa de Minas Gerais) and CAPES (Conselho de Aperfeiçoamento de Pessoal de Nível Superior) for the financial support. The authors also graciously thank all the staff of the common bean breeding program of the Federal University of Viçosa.

RESUMO: Na cultura do feijoeiro (Phaseolus vulgaris L.), a escolha de populações segregantes em programas de melhoramento conduzidos por seleção recorrente é etapa crucial, uma vez que se aumenta a chance de extrair linhagens superiores. A aplicação da metodologia de modelos mistos (REML/BLUP) na predição de valores genéticos tem mostrado bons resultados em programas de melhoramento animal e de culturas perenes, enquanto que em culturas anuais, sua utilização ainda necessita resultados adicionais. $\mathrm{O}$ objetivo deste estudo foi utilizar a metodologia REML/BLUP na seleção de populações segregantes em um programa de melhoramento de feijoeiro por seleção recorrente. Trinta e cinco populações $F_{3}$ foram avaliadas por meio de dados individuais de plantas quanto aos caracteres rendimento de grãos e diâmetro do hipocótilo. Os potenciais genéticos das populações foram estimados por meio da metodologia de modelos mistos e da metodologia de Jinks e Pooni. Um índice de seleção foi utilizado a fim de selecionar entre e dentro de populações para ambos os caracteres simultaneamente, por meio do BLUP de populações e de indivíduo. A metodologia de modelos mistos mostrou-se viável para predizer o potencial de populações segregantes, bem como para selecionar tais populações, considerando mais de um caráter ao mesmo tempo. A seleção de plantas individuais permite estimativas de ganho genético positivas para ambos os caracteres. Os valores genéticos preditos são de grande importância em um programa de melhoramento por seleção recorrente, pois permite escolher o número de populações e plantas individuais dentro de populações.

PALAVRAS-CHAVE: Phaseolus vulgaris. Índice de seleção. Seleção recorrente. Cultura autógama.

\section{REFERENCES}

ABREU, A. F. B.; RAMALHO, M. A. P.; SANTOS, J. B. Prediction of seed-yield potential of common bean populations. Genetics and Molecular Biology, Ribeirão Preto, v. 25, n. 3, p. 323-327, 2002.

tps://doi.org/10.1590/S1415-47572002000300013

ALVES, A. F.; MENEZES JÚNIOR, J. A. N.; MENEZES, V. M. P. S.; CARNEIRO, J. E. S.; CARNEIRO, P. C. S.; ALVES, A. F. Genetic progress and potential of common bean families obtained by recurrent selection. Crop Breeding and Applied Biotechnology, Viçosa, v. 15, n. 4, p. 218-226, 2015.

https://doi.org/10.1590/1984-70332015v15n4a38 
BATISTA, L. G.; DOS ANJOS, R. S.; POERSCH, N. L.; NALIN, R. S.; CARNEIRO, P. C. S.; CARNEIRO, J. E. S.; RESENDE, M. D. Multigeneration Index in the Selection of Common Bean Inbred Families. Crop Science, Madison, v. 57, n. 5, p. 2354-2360, 2017. https://doi.org/10.2135/cropsci2016.08.0665

BAUER, A. M.; REETZ, T. C.; LÉON, J. Estimation of breeding values of inbred lines using best linear unbiased prediction (BLUP) and genetic similarities. Crop science, Madison, v. 46, n. 6, p. 2685-2691, 2006. https://doi.org/10.2135/cropsci2006.01.0019

BERNAL-VASQUEZ, A. M.; UTZ, H. F.; PIEPHO, H. P. Outlier detection methods for generalized lattices: a case study on the transition from ANOVA to REML. Theoretical and applied genetics, Berlin, v. 129, n. 4, p. 787-804, 2016. https://doi.org/10.1007/s00122-016-2666-6

BERNARDO, R. Breeding for quantitative traits in plants. Stemma Press, 2002.

COWLING, W. A. Sustainable plant breeding. Plant Breeding, v. 132, n. 1, p. 1-9, 2013. https://doi.org/10.1111/pbr.12026

CUNHA, W. G.; RAMALHO, M. A. P.; ABREU, A. F. B. Selection aiming at upright growth habit common bean with carioca type grains. Crop Breeding and Applied Biotechnology, Viçosa, v. 5, n. 4, 2005. https://doi.org/10.12702/1984-7033.v05n04a02

ENTRINGER, G. C.; VETTORAZZI, J. C. F.; SANTOS, E. A.; PEREIRA, M. G.; VIANA, A. P. Genetic gain estimates and selection of $\mathrm{S} 1$ progenies based on selection indices and REML/BLUP in super sweet corn.

Australian Journal of Crop Science, v. 10, n. 3, p. 411, 2016. https://doi.org/10.21475/ajcs.2016.10.03.p7248

HENDERSON, C. R. Applicatıons of lınear models m animal breedıng. University of Guelph Press, Guelph, v. 11, p. 652-653, 1984.

HOLLAND, J. B.; NYQUIST, W. E.; CERVANTES-MARTÍNEZ, C. T. Estimating and interpreting heritability for plant breeding: an update. Plant Breeding Reviews, Purdue, v. 22, p. 9-112, 2010. https://doi.org/10.1002/9780470650202.ch2

JINKS, J. L.; POONI, H. S. Predicting the properties of recombinant inbred lines derived by single seed descent. Heredity, v. 36, n. 2, p. 253, 1976. https://doi.org/10.1038/hdy.1976.30

JOST, E.; RIBEIRO, N. D.; ROSA, D. P.; POSSOBOM, M. T. D. F.; MAZIERO, S. M. Methods of selecting common bean lines having high yield, early cycle and erect growth. Revista Ciência Agronômica, v. 45, n. 1, p. 101-110, 2014. https://doi.org/10.1590/S1806-66902014000100013

MENDES, M. P.; RAMALHO, M. A. P.; ABREU, A. F. B. Strategies in identifying individuals in a segregant population of common bean and implications of genotype $\mathrm{x}$ environment interaction in the success of selection. Genetics and Molecular Research, v. 11, n. 2, p. 872-880, 2013. https://doi.org/10.4238/2012.April.10.3

MENEZES JÚNIOR, J. A. N.; REZENDE JÚNIOR, L. S.; ROCHA, G. S.; PEREIRA, A. C.; CARNEIRO, P. C. S.; PETERNELLI, L. A.; CARNEIRO, J. E. S. Two cycles of recurrent selection in red bean breeding. Crop Breeding and Applied Biotechnology, v. 13, n. 1, p. 41-48, 2013. https://doi.org/10.1590/S198470332013000100005

MENEZES JÚNIOR, J. A. N.; CARNEIRO, J. E. S.; MENEZES, V. M. P. S.; CARNEIRO, P. C. S. Genetic potential of segregating populations of red beans conducted by the bulk method with selection. Genetics and Molecular Research, v. 15, n. 2, 2016. https://doi.org/10.4238/gmr.15027329 
MORAIS JÚNIOR, O. P. D.; MELO, P. G. S.; MORAIS, O. P. D.; CASTRO, A. P. D.; BRESEGHELLO, F.; UTUMI, M. M.; PEREIRA, J. A.; WRUCK, F. J.; COLOMBARI FILHO, J. M. Genetic progress after cycles of upland rice recurrent selection. Scientia Agricola, v. 72, n. 4, p. 297-305, 2015.

https://doi.org/10.1590/0103-9016-2014-0137

MOURA, L. M.; CARNEIRO, P. C. S.; VALE, N. M.; BARILI, L. D.; SILVA, L. C.; CARNEIRO, J. E. S.; CRUZ, C. D. Diallel analysis to choose parents for black bean (Phaseolus vulgaris L.) breeding. Genetics and Molecular Research, nov. 2016. doi: 10.4238/gmr.15038574. Retrive from http://www.locus.ufv.br/bitstream/handle/123456789/12813/gmr8574.pdf?sequence=1\&isAllowed=y

MOURA, M. M.; CARNEIRO, P. C. S.; CARNEIRO, J. D. S.; CRUZ, C. D. Potencial de caracteres na avaliação da arquitetura de plantas de feijão. Pesquisa Agropecuária Brasileira, v. 48, n. 4, p. 417-425, 2013. https://doi.org/10.1590/S0100-204X2013000400010

NYQUIST, W.E.; BAKER, R. J. Estimation of heritability and prediction of selection response in plant populations. Critical reviews in plant sciences, v. 10, n. 3, p. 235-322, 1991.

https://doi.org/10.1080/07352689109382313

OLIVEIRA, A. M. C.; BATISTA, R. O.; CARNEIRO, P. C. S.; CARNEIRO, J. E. S.; CRUZ, C. D. Potential of hypocotyl diameter in family selection aiming at plant architecture improvement of common bean. Genetics and Molecular Research, v. 14, n. 3, p. 11,515-11,523, 2015. https://doi.org/10.4238/2015.September.28.3

OTUBO, S. T.; RAMALHO, M. A. P.; ABREU, A. F. B.; DOS SANTOS, J. B. Genetic control of low temperature tolerance in germination of the common bean (Phaseolus vulgaris L.). Euphytica, v. 89, n. 3, p. 313-317, 1996. doi: 10.1007\%2FBF00022287.pdf.

PIEPHO, H. P.; MOHRING, J.; MELCHINGER, A. E. BLUP for phenotypic selection in plant breeding and variety testing. Euphytica, v. 161, n. 1-2, p. 209-228, 2008. https://doi.org/10.1007/s10681-007-9449-8

PIRES, L. P. M.; RAMALHO, M. A. P.; ABREU, A. F. B.; FERREIRA, M. C. Recurrent mass selection for upright plant architecture in common bean. Scientia Agricola, v. 71, n. 3, p. 240-243, 2014.

https://doi.org/10.1590/S0103-90162014000300009

RESENDE, M. D. V. Software Selegen-REML/BLUP: a useful tool for plant breeding. Crop Breeding and Applied Biotechnology, v. 16, n. 4, p. 330-339, 2016. https://doi.org/10.1590/1984-70332016v16n4a49

RESENDE, M. D. V.; DUARTE, J. B. Precisão e controle de qualidade em experimentos de avaliação de cultivares. Pesquisa Agropecuária Tropical, v. 37, n. 3, 2007.

RESENDE, M. D. V.; RAMALHO, M. A. P.; GUILHERME, S. R.; ABREU, A. F. A. Multigeneration index in the Within-Progenies bulk method for breeding of Self-Pollinated plants. Crop Science, v. 55, n. 3, p. 12021211, 2015. https://doi.org/10.2135/cropsci2014.08.0580

RESENDE, M. D. V.; RAMALHO, M. A. P.; CARNEIRO, P. C. S.; CARNEIRO, J. E. S.; BATISTA, L. G.; GOIS, I. B. Selection Index with Parents, Populations, Progenies, and Generations Effects in Autogamous Plant Breeding. Crop Science, v. 56, n. 2, p. 530-546, 2016. https://doi.org/10.2135/cropsci2015.05.0303

ROCHA, G. S.; CARNEIRO, J. E. S.; REZENDE, L. S.; MENEZES JÚNIOR, J. A. N.; CARNEIRO, P. C. S.; CECON, P. R. Effect of environments on the estimated genetic potential of segregating common bean populations. Crop Breeding and Applied Biotechnology, v. 13, n. 4, p. 241-248, 2013.

https://doi.org/10.1590/S1984-70332013000400004

SILVA, G. S. D.; RAMALHO, M. A. P.; ABREU, A. F. B.; NUNES, J. A. R. Estimation of genetic progress after eight cycles of recurrent selection for common bean grain yield. Crop Breeding and Applied Biotechnology, v. 10, n. 4, p. 351-356, 2010. https://doi.org/10.1590/S1984-70332010000400010 
VIANA, J. M. S.; DE ALMEIDA, I. F.; RESENDE, M. D. V.; FARIA, V. R.; SILVA, F. F. BLUP for genetic evaluation of plants in non-inbred families of annual crops. Euphytica, v. 174, n. 1, p. 31-39, 2010. https://doi.org/10.1007/s10681-009-0094-2

WESTNEAT, D. F.; WRIGHT, J.; DINGEMANSE, N. J. The biology hidden inside residual within-individual phenotypic variation. Biological Reviews, v. 90, n. 3, p. 729-743, 2015. https://doi.org/10.1111/brv.12131

WITCOMBE, J. R.; VIRK, D. S. Number of crosses and population size for participatory and classical plant breeding. Euphytica, v. 122, n. 3, p. 451-462, 2001. https://doi.org/10.1023/A:1017524122821 